\title{
Pubertas Terlambat pada Anak Thalassemia di RSAB Harapan Kita Jakarta
}

\author{
Hermien W Moeryono, Fajar Subroto, Aditya Suryansyah \\ Rumah Sakit Anak dan Bunda Harapan Kita, Jakarta
}

\begin{abstract}
Latar belakang. Thalassemia adalah salah satu penyakit kelainan darah yang cukup banyak diderita oleh anak-anak di Indonesia. Dengan penanganan thalassemia yang baik maka angka harapan hidup anak thalassemia meningkat. Transfusi darah terus-menerus menimbulkan masalah timbunan besi dalam tubuh, dan paling sering menyebabkan pubertas terlambat pada anak thalassemia.

Tujuan. Melihat angka kejadian keterlambatan pubertas pada anak thalassemia, kadar serum ferritin dan hubungannya dengan terapi kelasi besi yang didapat di RSAB Harapan Kita Jakarta.

Metode. Penelitian dilakukan secara deskriptif pada 14 anak thalassemia yang dirawat di Rumah Sakit Anak Bunda (RSAB) Harapan Kita dari 1 Januari 2008 - 31 Maret 2011. Data diambil dari rekam medis dan dianalisis dengan SPSS 17.0

Hasil. Pasien thalassemia anak dan berada dalam usia pubertas adalah 28,6\% laki-laki dan 71,4\% perempuan. Anak yang mengalami keterlambatan pubertas 5 anak (35,7\%), yaitu 2 anak (14,3\%) perempuan dan 3 anak $(21,4 \%)$ laki-laki. Kadar serum ferritin di atas $10000 \mathrm{ng} / \mathrm{mL}$ dijumpai pada 2 anak $(14,3 \%)$ dan 13 anak $(92,9 \%)$ memiliki status gizi kurang. Loss to follow up 4 anak $(28,6 \%)$ dan yang meninggal 2 anak $(14,3 \%)$. Rata-rata jumlah transfusi $108,6 \pm 42,3 \mathrm{cc} / \mathrm{kgBB} /$ tahun dan rata-rata kadar serum ferritin adalah $7130,1 \pm 3621,4 \mathrm{ng} / \mathrm{mL}$.

Kesimpulan. Angka kejadian pubertas terlambat pada thalassemia di RSAB Harapan Kita Jakarta adalah 35,7\%. Keterlambatan pubertas itu dapat karena deposit besi yang tinggi dalam tubuh dan terapi besi yang tidak adekuat. Selain itu pubertas juga dipengaruhi oleh status gizi dari anak tersebut. Anak thalassemia di RSAB Harapan Kita 92,9\% memiliki status gizi yang kurang. Untuk itu deteksi dini untuk melihat tanda-tanda pubertas pada anak thalassemia sangat diperlukan untuk anak perempuan yang sudah menginjak usia 8 tahun dan anak laki-laki 9 tahun sehingga penanganan dari keterlambatan pubertas dapat dimulai sejak awal. Dengan terapi kelasi besi yang adekuat diharapkan anak thalassemia mengalami perkembangan pubertas yang sama dengan anak normal. Sari Pediatri 2012;14(3):162-6.
\end{abstract}

Kata kunci: thalassemia, pubertas terlambat

\footnotetext{
Alamat korespondensi:

Dr. Hermien W Moeryono, SpA. Staf. Divisi Hematologi Anak RS Anak dan Bunda Harapan Kita Jakarta, Jl. Letjen S. Parman Kav. 87, Slipi. Telp. $+6221-5668284$
} 
$\mathrm{T}$ halassemia adalah salah satu penyakit kelainan darah yang cukup banyak diderita oleh anak- di Indonesia. Thalassemia banyak terdapat baik pada ras Melayu maupun Cina. ${ }^{1}$ Anak dengan penyakit thalassemia memerlukan transfusi secara terus-menerus untuk mempertahankan kadar $\mathrm{Hb}>9 \mathrm{~g} / \mathrm{dL}$ tergantung dari derajat anemia yang diderita. ${ }^{2}$

Thalassemia dibagi menjadi thalassemia mayor, thalassemia minor, dan thalassemia intermedia. Thalassemia yang lebih banyak terdapat di Asia Tenggara khususnya Indonesia adalah thalassemia $\beta$.

Faktor-faktor yang dikatakan memiliki kontribusi dalam etiologi dari kegagalan tubuh kembang anak thalassemia adalah adanya anemia kronis, toksisitas dari terapi kelasi besi deferoxamine, peningkatan konsumsi energi karena digunakan untuk hematopoiesis dan kerja jantung, defisiensi zat gizi seperti kalori, asam folat, zinc, dan vitamin A, gangguan homeostasis kalsium, dan kelainan pada tulang, serta disfungsi hepar dan pankreas. ${ }^{3,4}$

Pada saat ini pasien thalassemia dapat memiliki status kesehatan yang lebih baik dengan pemberian transfusi darah lebih dini. Tetapi transfusi darah itu juga membawakan masalah baru yaitu timbunan besi dalam tubuh pasien. Anak dengan thalassemia seringkali mengalami gangguan tumbuh kembang, dikarenakan anemia kronis yang diderita. Gangguan dari timbunan besi pada thalassemia yang paling sering adalah pubertas terlambat, diikuti amenorrhea sekunder, hipoparatiroid, hipotiroid, dan diabetes mellitus. ${ }^{3,4}$ Timbunan besi yang berlebih menyebabkan gangguan fungsi hati sampai gagal jantung. ${ }^{5}$ Timbunan besi dapat diatasi dengan pemberian kelasi besi seperti deferoxamine, deferasirox, maupun deferiprone. ${ }^{3}$

Pada thalassemia usia tulang mengalami keterlambatan pada umumnya di atas 6-7 tahun. Keterlambatan tumbuh kembang dapat dipengaruhi baik dari deposit besi di dalam tubuh maupun tingkat gizi/nutrisi. ${ }^{5}$ Pada fase pubertas perkembangan alat kelamin dipengaruhi oleh hormon pertumbuhan (growth hormone) dan sekresi dari hormon sex steroid. ${ }^{3,6,7}$

Kriteria keterlambatan tumbuh dari anak thalassemia terlihat dari tinggi badan anak yang berada di bawah dari -2SD (standar deviasi) atau anak tumbuh kurang dari $4 \mathrm{~cm} /$ tahun. Sedangkan pubertas yang terlambat tampak dari keterlambatan perkembangan payudara (telarche) atau menstruasi pertama (menarche) pada anak perempuan umur 13 tahun dan diameter testis $<4 \mathrm{~cm}$ pada anak laki-laki umur 14 tahun. ${ }^{4-6,8}$ Untuk mengatasi hal tersebut pasien thalassemia yang mengalami pubertas tersebut maka diperlukan terapi hormon yaitu pemberian estrogen atau testosterone untuk merangsang pubertas. ${ }^{6}$ Terapi hormon diberikan bekerja sama dengan Bagian Endokrinologi Anak untuk memantau perkembangan pubertas.

Tujuan dari penelitian untuk menilai angka kejadian pubertas terlambat pada anak thalassemia, kadar serum ferritin, dan hubungannya dengan terapi kelasi besi.

\section{Metode}

Penelitian retrospektif deskriptif, data diperoleh dari rekam medis pasien yang dirawat dengan diagnosis thalassemia di RSAB Harapan Kita Jakarta. Subjek adalah pasien thalassemia, usia pubertas, berobat di RSAB Harapan Kita dan di rumah sakit lain. Didapatkan 14 pasien thalassemia sejak 1 Januari 2008 sampai dengan 31 Maret 2011, terdiri dari 4 laki-laki dan 10 perempuan.

Kriteria inklusi adalah pasien thalassemia baik pasien lama maupun baru, usia pubertas, yaitu 14-18 tahun untuk anak laki-laki dan 13-18 tahun untuk anak perempuan. Setelah diagnosis thalassemia ditegakkan maka dilakukan skrining genetika untuk melihat jenis thalassemia. Kemudian dilakukan skrining untuk melihat berapa orang yang mengalami keterlambatan pubertas. Data yang didapat dianalisis dengan statistik SPSS 17.0 untuk windows. Dari analisis ditentukan karakteristik pasien thalassemia pada usia pubertas di Indonesia.

\section{Hasil}

Selama periode penelitian didapat 14 orang anak thalassemia yang berada pada usia pubertas. Karakteristik subjek tertera pada Tabel 1. Semua anak thalassemia tersebut menderita thalassemia $\beta$. Kadar serum ferritin yang di atas $10000 \mathrm{ng} /$ mL dijumpai pada 2 anak dan 13 anak memiliki gizi kurang. Dua anak yang meninggal dan 2 anak dilakukan splenektomi. Jadi subjek yang mengalami keterlambatan pubertas 5 anak. 
Kejadian hemosiderosis tertera pada Tabel 2, menggambarkun jumlah transfusi darah per tahun (cc/kgBB/tahun) dan kadar serum ferritin. Loss to follow up 4 anak dan yang meninggal 2 anak. Rata-rata jumlah transfusi $108,6 \pm 42,3 \mathrm{cc} / \mathrm{kgBB} /$ tahun dan rata-rata kadar serum ferritin adalah $7130,1 \pm 3621,4 \mathrm{ng} / \mathrm{mL}$. Semua anak tersebut mendapat terapi kelasi besi deferoxamine subkutan tidak adekuat (tidak teratur). Rata-rata umur anak pada penelitian $15,8 \pm 1,2$ tahun dan rata-rata jumlah transfusi $22,9 \pm 16,7$ kali.

Tabel 1. Karakteristik thalassemia di RSAB Harapan Kita, Januari 2008-Maret 2011

\begin{tabular}{lc}
\hline Karakteristik & Jumlah \\
\hline Jenis kelamin & \\
Laki-laki & 4 \\
Perempuan & 10 \\
Status gizi & \\
Normal & 1 \\
Kurang & 13 \\
Status pasien & \\
Hidup & 12 \\
Meninggal & 2 \\
Splenektomi & \\
Ya & 2 \\
Tidak & 12 \\
Keterlambatan pubertas & \\
Ya & 5 \\
Tidak & 7 \\
Laki-laki & 3 \\
Perempuan & 2 \\
\hline
\end{tabular}

Tabel 2. Hemosiderosis dan terapi kelasi besi

\begin{tabular}{lc}
\hline & Jumlah \\
\hline Jumlah transfusi (cc/kg BB/tahun) & \\
$\quad>100$ & 4 \\
$\quad<100$ & 10 \\
Kadar serum ferritin (ng/mL) & 2 \\
$\quad<10000$ & 12 \\
$\quad>10000$ & \\
Terapi kelasi besi & 0 \\
$\quad$ Adekuat & 14 \\
$\quad$ Inadekuat & \\
Status terapi pasien saat ini & 8 \\
$\quad$ Lanjut & 2 \\
$\quad$ Meninggal & 4 \\
$\quad$ Loss to follow up &
\end{tabular}

\section{Pembahasan}

Tanda keterlambatan pubertas pada anak yang menderita thalassemia terlihat dari tidak ada tanda menarche atau telarche pada anak perempuan di atas umur 13 tahun atau diameter testis $<4 \mathrm{~cm}$ dari anak laki-laki pada umur 14 tahun. Di antara 35 anak yang mengalami keterlambatan pubertas, yaitu 2 anak perempuan dan 3 anak laki-laki. Rerata mendapat terapi hormonal estrogen untuk anak perempuan dan dengan testosterone untuk anak laki-laki. Pemberian terapi hormonal yang diberikan bekerja sama dengan Bagian Endokrinologi RSAB Harapan Kita. Selain kriteria pubertas, juga dilakukan pemeriksaan kadar LH, FSH dan tes stimulasi dengan HCG (pada anak laki-laki) dan HMG (pada anak perempuan). ${ }^{4}$

Sebagian besar anak yang mengalami keterlambatan pubertas memiliki kadar serum ferritin di atas 5000 ng/mL, bahkan kadar tertinggi sampai $12471 \mathrm{ng} / \mathrm{mL}$. Insidens keterlambatan pubertas sebenarnya dapat dicegah atau dikurangi dengan terapi kelasi besi yang adekuat. ${ }^{4,59}$ Keterlambatan pubertas yang terjadi dapat karena kegagalan perkembangan gonad primer yang dikarenakan timbunan besi di ovarium dan testis atau kegagalan sekunder oleh karena siderosis di kelenjar pituitari. ${ }^{10}$

Terapi yang diberikan untuk memperbaiki keterlambatan pubertas adalah terapi hormonal seperti testosterone, HCG, dan estrogen maupun L-carnitine terapi. Dilaporkan keterlambatan pubertas juga dapat dikarenakan defisiensi dari L-carnitine sekunder sehingga dengan pemberian suplemen L-carnitine, pertumbuhan, dan kadar LH (luteinizing hormone) meningkat. ${ }^{5,11}$ Pada anak thalassemia kejadian hipoksemia, hemosiderosis, dan peningkatan konsumsi energi dapat menyebabkan defisiensi carnitine sekunder. ${ }^{5}$ Sehingga baik terapi pengganti hormonal (hormonal replacement therapy) maupun terapi dengan L-carnitine dampak positif bagi anak thalassemia yang menderita keterlambatan pubertas., ${ }^{5,11}$

Terapi pengganti hormonal untuk anak lakilaki adalah depot testosterone IM 25-50 mg untuk 6 bulan, kemudian dinilai ulang tanda-tanda pubertas. Jika masih belum ada tanda-tanda pubertas, dosis testosteron dinaikkan menjadi $100 \mathrm{mg} / \mathrm{bulan}$ untuk 1 tahun. Untuk anak perempuan diberikan estrogen oral (ethynilestradiol) $100 \mathrm{ng} / \mathrm{kg} / \mathrm{hari}$ untuk 6 bulan dan dapat dinaikkan menjadi $200 \mathrm{ng} / \mathrm{kg} /$ hari. Untuk menginduksi menarche dapat digunakan 
medroxyprogesterone $10 \mathrm{mg} /$ hari selama 10 hari jika ukuran uterus telah mencapai $5 \mathrm{~cm}$. Jika anak sudah mencapai pubertas maka dosis hormon testosterone dan estrogen disesuaikan untuk masing-masing anak (dosis maintenance). ${ }^{2}$

Penyebab keterlambatan pubertas adalah timbunan besi dalam tubuh maka diperlukan terapi kelasi besi yang benar dan adekuat untuk mencegah kelainankelainan yang disebabkan karena timbunan besi. Terapi kelasi besi yang diberikan adalah deferoxamine subkutan, deferiprone oral, maupun deferasirox oral satu kali sehari (once daily). Hasil terapi kelasi besi kombinasi deferiprone dan deferoxamine lebih baik untuk jantung dan hati daripada deferasirox, deferiprone maupun deferoxamine diberikan terpisah. ${ }^{12-14}$

Selain karena timbunan besi kegagalan pubertas dapat juga disebabkan karena gizi yang tidak baik. Pada anak thalassemia di RSAB Harapan Kita hampir semua menderita gizi kurang $(92,9 \%)$ dan hanya satu anak dengan gizi baik. Anemia kronis yang diderita anak thalassemia juga makin menurunkan keadaan gizi sehingga dapat menjadi salah satu faktor yang menyebabkan keterlambatan pubertas. ${ }^{4}$ Makin buruk gizi anak semakin mudah terkena infeksi. Oleh karena anak thalassemia (40\%) mengalami defisiensi zinc. Preparat pemberian zinc pada anak thalassemia pada umur 1-7 tahun dapat memperbaiki pertumbuhan. ${ }^{15}$ Selain itu anak 50\%-100\% mengalami defisiensi vitamin $\mathrm{D}$, tetapi dapat diperbaiki dengan pemberian terapi cholecalciferol selama 3 bulan. ${ }^{16}$

Thalassemia anak yang mengalami keterlambatan pubertas seharusnya diperiksa kadar hormon FSH, LH, estradiol, testosterone, GnRH, HCG, dan HMG secara berkala baik untuk mendeteksi keterlambatan pubertas maupun sebagai indikator keberhasilan terapi hormonal. Sebaiknya anak perempuan yang sudah mendapat menarche juga tetap dipantau untuk mendeteksi amenorrhea sekunder. ${ }^{5}$

\section{Kesimpulan}

Pubertas yang terlambat banyak terjadi pada anak dengan thalassemia yang tidak mendapat terapi kelasi besi dengan adekuat. Angka kejadian pubertas yang terlambat di RSAB Harapan Kita Jakarta adalah $35,7 \%$. Keterlambatan pubertas itu dapat karena deposit besi yang tinggi dalam tubuh dan terapi besi yang tidak adekuat. Rata-rata kadar serum ferritin anak thalassemia di RSAB Harapan Kita 7130,1 $\pm 3621,4$ $\mathrm{ng} / \mathrm{mL}$ dan semua anak tidak mendapatkan terapi kelasi besi yang adekuat. Selain itu pubertas juga dipengaruhi oleh status gizi 92,9\% anak memiliki status gizi kurang. Oleh karena itu mendeteksi dini untuk melihat tanda-tanda pubertas pada anak thalassemia sangat diperlukan, untuk anak perempuan usia 8 tahun dan anak laki-laki 9 tahun sehingga pengobatan dapat dimulai lebih dini. Dengan terapi kelasi besi yang adekuat diharapkan anak thalassemia mengalami perkembangan pubertas yang sama dengan anak normal.

\section{Daftar pustaka}

1. Ismail A, Campbell MJ, Ibrahim HM, Jones GL. Health related quality of life in Malaysian children with thalassemia. Health and Quality of Life Outcomes 2006;4:39.

2. Kyriakou A, Skordis N. Thalassemia and aberrations of growth and puberty. Mediterranean J Hematol and Infect Dis 2009; 1: e2009003.

3. Galanello R, Origa R. Beta-thalassemia. Orphanet J Rare Dis 2010;5:11-8.

4. Batubara JRL, Akib A, Pramita D. Delayed puberty in thalassemia major patients. Paediatr Indones 2004; 7-8: 143-8.

5. El Beshlaw AE, Mohtar G, Ghafar EA. Assesment of puberty in relation to L-carnitine and hormonal replacement therapy in -thalassemic patients. J Trop Paediatr 2008; 6: 375-81.

6. Soliman AT, Khalafallah H, Ashour R. Growth and Factors Affecting in Thalassemia Major. Hemoglobin. 2009 ; 33 : S116-S26.

7. Herbert L, Muncie JR. MD, and Campbell, MD. Alpha and beta thalassemia. Am Fam Phys 2009; 80: 4-9.

8. Moayeri H, Oloomi Z. Prevalence of growth and puberty failure with respect to growth hormone and gonadotropin secretion in beta-thalassemia major. Arch Iranian Med 2006;9: 329-34.

9. Raiola G, Golati MC, De Sanctis V. Growth and puberty in thalassemia major. J Pediatr Endocrinol Metab 2003; (suppl 2): 259-66.

10. Aydinok Y, Darcan S, Polat A. Endocrine complications in patients with $\mathrm{B}-$ thalassemia major. J Trop Pediatr 2003;48:50-4.

11. El Beshlawy A, Abdel Dayem S, Abd El Raouf E. Effect of L-carnitine on growth of Egyptian children with thalassemia major. Med J Cairo Univ 2001;69:7-12. 
12. Pepe A, Meloni A, Capra M. Deferasirox, deferiprone and desferrioxamine treatment in thalassemia major patients: cardiac iron and function comparison determined by quantitative magnetic resonance imaging. Haematologica 2011;96:41-7.

13. Maggio A, Vitrano A, Capra M. Improving survival with deferiprone treatment in patients with thalassemia major: A prospective multicenter randomised clinical trial under the auspices of the Italian Society for Thalassemia and Hemoglobinopathies. Blood Cells, Molecules, and Diseases 2009; 4: 247-51.
14. Berdoukas V, Chouliaras G, Moraitis P, Zannikos K, Berdoussi E, Ladis V. The efficacy of iron chelator regimes in reducing cardiac and hepatic iron in patients with thalassemia major: a clinical observational study. $J$ Cardiovasc Magnetic Resonance 2009;11:20.

15. Arcasoy A, Cavdar A, Cin S. Effects of zinc supplementation on linear growth in beta-thalassemia (a new approach). American Journal Hematology. 1987; 24: 127-36.

16. Wood JC, Claster S, Carson S. Vitamin D deficiency, cardiac iron, and cardiac function in thalassemia major. British J Haematol 2008;141:891-4. 